University of Washington Tacoma

UW Tacoma Digital Commons

$11-1-2021$

\title{
Mapping and Managing Organization Objectives: A Case Study of the Alto Maipo Hydroelectric Project in Chile
}

Jeffrey P. Walters

University of Washington Tacoma, jpwalt@uw.edu

Hernán Alcayaga

Carolina Busco

Tamara Araya

Follow this and additional works at: https://digitalcommons.tacoma.uw.edu/tech_pub

\section{Recommended Citation}

Walters, Jeffrey P.; Alcayaga, Hernán; Busco, Carolina; and Araya, Tamara, "Mapping and Managing Organization Objectives: A Case Study of the Alto Maipo Hydroelectric Project in Chile" (2021). School of Engineering and Technology Publications. 434.

https://digitalcommons.tacoma.uw.edu/tech_pub/434

This Article is brought to you for free and open access by the School of Engineering and Technology at UW Tacoma Digital Commons. It has been accepted for inclusion in School of Engineering and Technology Publications by an authorized administrator of UW Tacoma Digital Commons. 


\title{
- Mapping and Managing Organization Objectives: A Case Study of the Alto Maipo
} Hydroelectric Project in Chile

\author{
Jeffrey P. Walters*a , Hernán Alcayaga ${ }^{\mathrm{b}}$, Carolina Busco ${ }^{\mathrm{c}}$, Tamara Araya ${ }^{\mathrm{d}}$ \\ ${ }^{a}$ Assistant Professor, George Fox University, Department of Civil Engineering, College of \\ Engineering, 414 N. Meridian ST, Newberg Oregon, 97132 USA \\ ${ }^{\mathrm{b}}$ Associate Professor, Universidad Diego Portales, Department of Civil Engineering, College of \\ Engineering and Applied Science, Av. Ejército 441, Santiago, Chile \\ ${ }^{\mathrm{c}}$ Assistant Professor, Universidad Diego Portales, Department of Industrial Engineering, College of \\ Engineering and Applied Science, Av. Ejército 441, Santiago, Chile \\ ${ }^{\mathrm{d} I n t e r n a t i o n a l ~ P r o g r a m s ~ E x e c u t i v e, ~ Z u r i c h ~ I n s u r a n c e ~ C o m p a n y ~ L t d ., ~ C o r p o r a t e ~ C e n t e r, ~ A u s t r a s s e ~ 46, ~}$ \\ 8045 Zurich, Switzerland \\ *Corresponding Author, jwalters@georgefox.edu
}

Keywords: Hydroelectric; Integrated Water Resources Management; Systems Perspective; Organization Management; MACTOR; Conflict

\begin{abstract}
This study presents a process that uses the method of alliances, conflicts, tactics, objectives and recommendations (MACTOR) to inform integrated water resources management (IWRM) strategies for complex, multi-organization hydroelectric projects. This process is applied to the Alto Maipo Hydroelectric Project (AMHP) in Chile. The process enabled qualitative and quantitative insight on the interconnected aspects of alignment and conflict between AMHP organizations by mapping the 'battlefield' on which they converge or diverge based on their organizational objectives and relative levels of influence. Study findings reveal environmental protection and water provision are the core objectives around which conflicts center. Study findings also point to a nuanced power struggle between state and local organizations that undermines project productivity. Project recommendations focus on improving communication and collaboration between aligned yet siloed organizations and on improving the mechanisms for information flow and advocacy for local community and governmental organizations. These findings demonstrate the utility of the MACTOR approach - as it is applied within the proposed process - as a way to inform IWRM strategies for multi-organization hydroelectric projects from a systems perspective.
\end{abstract}




\section{INTRODUCTION}

It is becoming increasingly challenging to plan and manage water resources in light of water

44 scarcity, pollution, and a growing percentage of the population moving to urban centers (United

45 Nations et al. 2019). In the midst of these challenges, Integrated Water Resources Management

46 (IWRM) offers a means to address the complex and multidimensional linkages between the various

water resource stakeholder groups (Davis 2007; Gallego-Ayala and Juízo 2014; Suárez et al. 2014;

Hargrove and Heyman 2020). A core goal of IWRM is to thoughtfully consider and apply the knowledge of a diverse range of stakeholder groups to optimize social and economic benefits while not compromising resource sustainability (Hassing et al. 2009; Suárez et al. 2014; Davis 2007; Werkheiser and Piso 2015).

Large hydroelectric projects provide a salient backdrop for the use of IWRM strategies, especially related to conflict mitigation and the sustainable and equitable provision of both water and energy resources (Jusi 2013). Hydroelectric projects often fall within the realm of 'megaprojects', given their high cost and the impact they pose on society, the environment, and on the resources they depend upon (Ansar et al. 2014; Flyvbjerg 2014; Sovacool and Bulan 2011). Like most megaprojects, large hydroelectric projects involve multiple organizations from both public and private sectors. Here we define an organization as any organized group of stakeholders that may affect or be affected by the achievement of the purpose or purposes of a project (Freeman et al. 2010). Separate from an unorganized group of individual stakeholders, such as water or energy consumers, organizations have concrete objectives and a spokesperson who can represent the organization in an articulated manner.

As a result of the inherently complex organizational environment within which large hydropower projects exist and operate, the true influence organizations can have on project development and management is extremely variable (Bourne and Walker 2006). objectives (Davis 2007). The process of management throughout and beyond the construction of megaprojects have been widely discussed in the literature, with the chief objective of obtaining the support of the many organizations involved (Ignatius Teye Buertey 2016). Yet it remains challenging 
to navigate the complex drivers of alignment or misalignment of organizations based on their objectives and interests, often leadingto conflict and suboptimal project outcomes and increased project costs (Flyvbjerg et al. 2003; Ignatius Teye Buertey 2016; Jergeas et al. 2000; Newcombe 2003; Yang and Shen 2015). There have been many past instances where hydroelectric projects were not implemented due to their potential and perceived impacts on the environment and on local communities. For example, in the Chilean Patagonia, the Alumysa Aluminum Reduction Plant project (US \$ 2.75 billion) was discarded in 2006 (Dashwood 2012) and the HydroAysen hydroelectric generation project (US \$ 3.2 billion) discarded in 2014 (Merino and Bello 2014), both as a result of the strong demands of environmentalist and local community organizations. These examples, and many others, show the participation, and perception, of relevant organizations in the development of a megaproject in general, and a hydroelectric project in particular, can have a critical impact on project success (Davis 2007). This highlights the impetus for IWRM strategies that undergird and support productive communication and collaboration surrounding the economic, social and environmental implications of large hydroelectric projects.

As a large hydropower project located within the fragile multi-use Río Maipo watershed, the Alto Maipo Hydroelectric Project (AMHP) located 60km southeast of the capital city, Santiago [population 7.1 million (INE 2018)], Chile, in the Cajón del Maipo, offers a compelling multiorganization IWRM case study. Since its inception, many regional water supply utilities, rural potable water organizations (APRs), citizen activist groups, farmers, and social organizations, including the urban water service company Aguas Adinas, have vehemently opposed AMHP. They claim the project threatens the security and supply of potable water to the seven million inhabitants in the Santiago Metropolitan region, including farmers with 120,000 ha of irrigation and ten rural communities where drinking water is supplied by APR systems. APRs, which are managed, maintained and operated by the local community, have different regulation and performance frameworks than urban water companies such as Aguas Adinas. Some predictable environmental impacts from project construction include river sedimentation, area desertification, and significant reduction in groundwater recharge rates (SEA 2018). In contrast, advocates purport AMHP will bring much needed employment and innovation to the region, and bolster energy security in Chile (SEIA 
2007). Despite these conflicting perspectives, a marked underestimation of implementation costs (initially US\$700 million USD, now 3.05 billion) coupled with market challenges (Torrealba 2018), it is estimated that the Alto Maipo project will begin injecting electricity to the Central Interconnected System (SING) in late 2021 (Ministry of Energy 2012; El Mercurio 2020).

Past water resource experts have sought to promote IWRM strategies for basin management in Chile (Donoso 2018). Despite these efforts, however, there are still no policies in Chile that explicitly consider critical issues, such as social equity, environmental protection, environmental management, coordination of different uses and conflict resolution, all key aspects of an IWRM plan (Bauer 2009, 2015; Suárez et al. 2014). A history of neoliberal water management model undergirds this outcome, which fundamentally favors large private corporations, especially hydropower projects (Bauer 2015). Chile has a long history of water-related conflicts - initiated and promulgated by the Chile 1981 Water Code, which officially established that water resources are national and public goods. In this legal framework, water rights could be commercialized and transferred as a commodity between private parties (Bauer 2009, 2015; Bitran et al. 2014; Correa-Parra et al. 2020). While the 1981 water code has since been modified in 2005 , critics still point to this law as a key hindrance to IWRM policy and practice in Chile (Bauer 2015; Bitran et al. 2014). When referring to larger hydroelectric projects, the complexity and issues around IWRM are further confounded by the clout and prominence of Chilean energy law, further privileging private access to water resources for energy creation (Bauer 2009, 2015). Bauer (2015 p. 147) echoes these points, stating, "the critical problem of the Chilean water model is the lack of institutional capacity for governance or integrated water resources management, and the problem has worsened as water conflicts have become closely linked to conflicts in the energy and environmental sectors.”

By virtue of the inherent interdependence of social, environmental, technical, political and economic impacts of large hydropower projects, IWRM strategies requires a systems-lens through which to manage the objectives of organizations in order to promote just and equitable distribution of resources, and to mitigate conflict (Grigg 2016; Hassing et al. 2009; UNDP 2008). Past research has focused on ways to visually and quantitatively analyze and interpret the systemic interaction between organizations. One powerful approach is the 'Stakeholder Circle', developed by Bourne and Walker 
125 (2005), that provides an effective means to visualize the set of organization in a project, and offers a

126 systematic way to represent the pattern of influences between these organizations. However, a

127 weakness of this approach is the lack of identification of organizational attitudes or positions, as it

128 does not reflect whether the organizations perceive the project positively or negatively Mok et al.

129 (2015). Other studies, such as Rowley (1997), point to the use of social network analysis (SNA) as a

130 way to understand the structural characteristics of the organizational network, wherein organizational

131 influence is limited by patterns of relationships with other organizations inside the network structure

132 (Wasserman and Galaskiewicz 1994). SNA is a useful method to examine the simultaneous influence

133 of multiple organizations, and to predict corresponding responses and organizational strategies

134 (Chinowsky et al. 2008; Rowley 1997). However, SNA does not allow for the explicit consideration

135 of competition and power dynamics between organizations.

136 Similar to these studies, we posit that informing a IWRM strategy for the Río Maipo

137 watershed following completion of the AMHP, as well as future water basin management strategies in

138 Chile, requires a systems perspective to expose and decipher the complex and nuanced

139 interconnections between organizations. Considering that the key sources of organizational alliances

140 or conflicts are rooted in the alignment or discord between enmeshed organizational interests and

141 objectives, we propose a multi-step stakeholder mapping process that uses the MACTOR (Matrix of

142 Alliances and Conflicts, Tactics, Objectives and Recommendations) method to quantify, map and

143 evaluate the balance of power between different organizations based on their converging or diverging

144 objectives (Arcade et al. 2009; Godet 1991, 1994). This process seeks to leverage the strengths of the

145 aforementioned approaches that map the patterns of influence between organizations with the explicit

146 framing of organizational competition and power-struggles that often lead to conflicts.

147 Outputs from MACTOR analyses take the form of influence maps and network diagrams that

148 represent scenarios for how organizations form alliances (convergences) or present conflicts

149 (divergences). These diagrams highlight organizations that have the greatest overall influence on the

150 other organizations as well as overall project outcomes, and reveal the project objectives that have the

151 most significant alignment or misalignment. The resulting analysis offers systems-level insight for

152 how to leverage and promote existing organizational alliances and minimize confounding conflicts 
153 that negatively impacts an organization's objectives, operations or existence (Vivanco-Aranda et al.

154 2011). Given its strength to emerge systems-level insights for complex multi-organization projects,

155 the MACTOR approach has been applied within many contexts, including planning in development,

156 labor and employment (Bettencourt 2010), socio-economic development (de Figueiredo Porto et al.

157 2010), air transportation (Godet 1976), food supply-chains (Vivanco-Aranda et al. 2011), and photo-

158 voltaic technology innovation (Lo et al. 2013).

159 In the sections that follow, we present a replicable mixed-method data collection and analysis

160 process based on the MACTOR approach to address research questions (RQs) related to IWRM

161 strategies of the Río Maipo watershed in light of AMHP. We then conclude with a discussion of the

162 study findings and associated policy recommendations. The RQs that guided this study are:

163 RQ1: How do AMHP organizations align or misalign based on their objectives regarding the use of the Río Maipo watershed?

RQ2: What appears to be the objectives or desires where conflict or alignment exists between these organizations?

RQ3: What does this systems analysis reveal about the interaction between AMHP

\section{METHODS} organizations in particular, and inform for future pursuits of IWRM in Chile in

Below we outline the mixed-method process used to collect and analyze data on AMHP organization objectives and influence culminating with the MACTOR method. With the intention of promoting future replication of this process to other IWRM contexts, we detail the following steps below: i) identification of key organizations through a thorough review of secondary data (e.g., documents and reports); ii) supplementary interviews with organization representatives, iii) coding of challenges, objectives and organizational influence from the secondary data and complemented by

177 transcribed interviews, iv) MACTOR analysis, and v) Insights and recommendations. Data collection

178 and analysis rested heavily on secondary data sources to minimize the subjectivity that comes from

179 perception - using interviews to both corroborate with and add nuance to the challenges, objectives, 
and organizational influences identified via the secondary data. Figure 1 summarizes each step of

181 this process below with an overview of methods and outputs for each step. As many steps were

182 complimentary and required outputs from the previous step to proceed to the next, we combine

183 selected study results from each step to facilitate the elaboration of the multi-step research process. In

184 the subsequent sections, we further detail, analyze, and discuss the study findings.

\section{Step 1: Identification of Organizations}

186 A thorough review of secondary data covering topics of interaction and conflicts between

187 related AMHP organizations enabled the creation of an exhaustive list of organizations to participate

188 in the study. Secondary data sources included documents and reports, official web pages, social

189 media pages, press releases and the public environmental impact evaluation (SEIA 2007), all

190 representing the interests, vision, and objectives of the various organizations. Additional

191 organizations were identified through snowball sampling from the reviewed documents and from

192 study interviewees who were asked to indicate which organizations they interact with most (Palinkas

193 et al. 2015). Creators of the MACTOR approach recommend identifying between ten to 20 key

194 organizations to maximize the ability of the approach to characterize the complex interplay of these

195 organizations, while avoiding outputs that are overwhelming and uninterpretable (Godet 1994). In

196 total, eleven organizations were selected for this study. Table 1 provides a list of the organizations,

197 their organizational role, as well as the secondary data sources for each organization that were used

198 throughout the subsequent steps in the process.

199

\section{Step 2: Interviews with Organizational Representatives}

We conducted semi-structured interviews with organizational representatives to identify their positions, interests, motivations, limitations, and available resources to face conflicts with other organizations, and to provide qualitative richness and cross-validation of findings from the secondary

204 data. Secondary data and interviews together provided the required inputs - objectives and inter-

205 organizational influence - for the MACTOR analyses.

An interview protocol was discussed and validated by our research team and approved by the

207 Universidad Diego Portales Research Ethics Committee. The research team consisted of the four co- 
authors of this paper, including two civil engineering academics with knowledge about the MACTOR method and water resources management, an industrial engineering undergraduate student, and a sociologist with specialization in stakeholder conflict. The interview instrument was applied in

211 person. Although the intention was to interview at least one individual from each organization, 212 organizations who did not participate in the interviews were: Aguas Andinas (AA), Maipo Canal 213 Society (SCM), National Forest Company (CONAF), and the Ministry of the Environment (MMA).

214 For these organizations, the necessary information on their objectives and interaction with other 215 organizations was inferred from the answers given by the interviewees and corroborated with the 216 secondary data sources show in Table 1.

217 The following five questions were asked for the organizations who participated in the 218 interviews:

1. What is the vision of your organization regarding the Alto Maipo hydroelectric project?

2. What effects does the development of the Alto Maipo hydroelectric project have on your organization?

3. What are your organization's objectives at a general level and in relation to the Alto Maipo

\section{Step 3: Qualitative coding of secondary data and transcribed interviews}

Secondary data and transcribed organization interviews were qualitatively analyzed in Spanish to retain contextual richness and nuance. Transcripts were deductively coded within an Excel spreadsheet, with the purpose of extracting relevant information for the MACTOR analysis, specifically: challenges, objectives, strategies, inference of influence strength (described in Step 4) between organizations (Godet 1994). Table 2 presents the nine challenges and associated objectives that emerged from qualitative coding.

\section{Steps 4 \& 5: MACTOR Analysis \& Associated Recommendations}

Our research team met in four, five-hour sessions to discuss and evaluate the aforementioned influences, challenges, and associated objectives of AMHP organizations emerging from the 
secondary data and interview responses (Godet 1991, 1994). The aim of these sessions was to

237 systematically score organization influence and impact from project objectives. Subjectivity on

238 scoring was minimized through focused discussion and consensus between research team members

239 and supported using quotes from the organization's representative and supplemental documentation.

240 Influence strengths and impacts of organization objectives were housed within two matrices required

241 for the MACTOR analyses: the Matrix of Direct Influence (MDI) and the Matrix of Valued Positions

242 (2MAO).

243 The MDI is a square matrix that houses ordinal scoring on the level of organization influence

244 (impact of an organization's influence on the other organizations) and dependence (impact on an

245 organization by the influence from other organizations). The strength of influence between

246 organizations are classified on a scale of 0 to 4 according to the following criteria on the pair-wise

247 impact a particular organization has on the other organizations' processes, project, mission, or

248 existence:

$249-\quad$ 0: No influence or dependency.

$250-1$ : There is influence on the organization's processes; where a process is an everyday or minor task or operation the organization undertakes in achieving its mission.

- 2: There is influence on the organization's projects; where a project is a major effort by the organization to achieve its mission.

- 3: There is influence on the organization's mission; where the mission is an organization's reason for existence.

- 4: There is influence on the organization's existence

The $2 \mathrm{MAO}$ is a square matrix that houses qualitative scoring on the impact achievement of AMHP objectives have on the organization's processes, projects, mission, and existence. For each organization, the valuation is classified against each objective on a scale of -4 to 4 , where the sign indicates how achieving said objective would result in a favorable (+) or undesirable (-) influence on the organization. The analysis is performed based on the following criteria:

- 0 : The organization is indifferent to the objective being met.

- 1: Achieving the objective influences the operative processes of the organization. 
- 2: Achieving the objective influences the implementation of projects by the organization.

- 3: Achieving the objective influences the mission of the organization.

- 4: Achieving the objective jeopardizes the existence of the organization. Analyses performed on the MDI and 2MAO offer insight into an organization's power of influence and their alignment with other organizations, respectively. In particular, the mathematical operation of these two matrices can be used to infer i.) the combined direct and indirect influence between organizations, ii.) the relative level of power of each organization, iii.) the alignment (convergence) between organizations, iv.) the conflict (divergence) between organizations, and v.) major objectives or issues that drive alignment or conflict. All matrix manipulations were performed using the Lipsor/EPITA MACTOR software (EPITA 2010), where the matrix mathematics are per the MACTOR method outlined in Godet (2007) and presented in the Appendix. Evaluation of the combined direct and indirect influence between organizations takes place within the Matrix of Direct and Indirect Influences (MDII), which combines direct (i.e., Organization A on Organization B) and indirect influence scores (Organization A on Organization B, through interaction with Organization C).

Evaluation of an organization's relative level of power $\left(R_{i}^{*}\right)$ entails systematically comparing each organization's level of influence and dependence based on the MDII matrix. Values of $R_{i}^{*}>$ 1.0 implies an organization has an above-average power or competition over other organizations, while $R_{i}^{*}<1.0$ implies a level of power less than the average and thus a disproportionate vulnerability to other organizations within this battlefield. Evaluation of an organization's convergence and divergence combines information from both the MDI, 2MAO, MDII matrices to characterize the overall extent of an organization's alignment or conflict on project objectives - considering an organization's power struggles as inferred by the level of power score $R_{i}{ }^{*}$. The resulting output is the weighted valued position matrix 3MAO, used to calculate the weighted value matrix of convergences 2CAA (positive, alignment) or the weighted value matrix of divergences 2DAA (negative, conflict) by multiplying the respective positive and negative values contained in the $2 \mathrm{MAO}$ by their transpose. 3CAA is calculated as the average 
intensity (weighted score) for organizations who hold the same position (whether positive or

292 negative), where 3DAA is the same calculation by for organizations who hold opposite positions (i.e.,

293 one positive and one negative). Results from 3CAA and 3DAA are presented as a network diagram

294 to highlight areas of strong alignment or conflict within the AMHP project battlefield.

295 Finally, evaluation of the major objectives where alignment or conflict culminate, entails subtracting the valued convergence matrix (2CAA) from the valued divergence matrix (2DAA) to create a new matrix (2MOO), and an associated graph of the net distance between objectives. A smaller net distance between objectives indicates a higher level of alignment between stakeholders on these objectives.

\section{RESULTS}

This section presents the findings from the MACTOR analysis of AMHP organizations. The analysis begins by presenting results from the relationship between influence and power, followed by the assessment of organizational convergence (alliances) and divergence (conflicts). It concludes with an assessment of the overall level of organizational alignment or misalignment on project objectives.

\section{Organization Influence and Power (MDII Analysis)}

Analysis of an organization's direct and indirect influence uses the MDI created by the research team. The complete MDI is presented in the Appendix Table A1. Calculation of indirect interactions per equation 1 for creation of MDII, enabled creation of a factor influence map and evaluation on the level of power $\left(\mathrm{Ri}^{*}\right)$, presented in Figure 2 below. An influence map provides a two-dimensional analysis of the relative influence and dependence for each organization. In addition,

311 an influence map shows the relative power and vulnerability of each organization (Arcade et al.

312 2009), thereby providing supplemental insight into alignment and conflict and power struggles surrounding project or program objectives (presented in the subsequent sections). High influence

314 scores indicate that an organization has the capacity to influence one or more organizations' mission 315 or existence. 
318 virtuous or vicious project outcomes. It can be seen that AES-GEN (Ri* 1.09) has the largest

319 influence and dependence with other organizations - meaning they have a high potential for influence,

320 while also having a high vulnerability to the decisions and actions of the other organizations. NO-AM

321 (Ri* 0.95) also has a moderate level of influence and is yet vulnerable to outside organizations,

322 especially state agencies. It can be seen that the state agencies, such as CONAF (Ri* 1.45), MMA

323 (Ri*2.02) and DGA ( $\mathrm{Ri}^{*}$ 1.70), all appear in the upper-left quadrant of the influence map, indicating

324 a high level of influence and low level of vulnerability to other organizations. This high level of

325 influence and low level of vulnerability is reflected by their high level of power scores (Ri*), where

326 we see the top three scores are for these three state agencies. This shows the important role of these

327 agencies in the context of water and land management in Chile. When asked about the dependence of

328 AES-GEN on DGA and MME, the AES-GEN interviewee highlights the Chilean law that undergirds

329 and gives power to these two agencies:

330 "DGA has to give permission for a lot of our processes, so their authorization role as the environmental institution is important in our process. Nowadays, when its superintendency has to audit us, they invite all the other agencies, so they can all see if

Similarly, regarding their dependence on the MMA, the AES-GEN interviewee indicated:

"The MMA has been the most influential ministry for the project construction, because its superintendency can prevent the project from being carried out. The ministry dictates the general policies, processes bills, etc. But is the superintendency who supervises and meaning their influence over AES-GEN is large. Interestingly, AA was initially included in the list of opposing organizations, claiming that the AMHP threatened the security and continuity of Santiago's drinking water service (SEIA 2008). However, in June 2011, AA signed a contract with AES-GEN, in which they gave $2.5 \mathrm{~m}^{3} / \mathrm{s}$ of drinking water from Santiago to AES-GEN and, in addition, leased the back-up infrastructure from the tariff system to the electric power generating company, and seeing an 
economic benefit from pre-sedimentation by the hydro-plant turbines (CIPER 2011; INDH 2012). As

347 the AES-GEN interview corroborates:

"AA were neutral at the beginning, but later on understood they had an opportunity, because the project allowed them access to water, independently of climate or stationary issues. On the other hand, the Andean water catchments are all downstream from the project's return point to the river, therefore they can use the water that passes through the turbines without sediments, and their treatment process will be then much easier for them."

Organizations with lesser influence and greater dependence on other organizations included the local community organizations (COM, $\mathrm{Ri}^{*} 0.09$; $\left.\mathrm{CTCM}, \mathrm{Ri}^{*} 0.39\right)$ and the local government (MSJM, Ri* 0.18). Indeed, local communities and governments are often the ones who are most vulnerable and who experience the greatest impact from large hydro projects (Goodwin et al. 2006; Latta 2007; Maher 2019). When asked about the engagement between AES-GEN and MSJM, the AES-GEN interviewee indicated the importance of engaging the local municipality in discussion on socio-economic and socio-environmental effects from the project. While they appreciated the way in which the municipality aids in project operation, they mentioned the low level of power the municipality has to impede project progress or existence. projects, is a close partner for us. For example, when facing snow or floods during the winter operation, we provide logistical support in order to allow fluid transit. We try to keep a very close relationship. But as a good neighbor, we must have a good relationship with the municipality - that is essential." influence the other organizations (Goodwin et al. 2006), as indicated by a low Ri* score. This reality was expanded upon by the MSJM representative: 
"The institutional role of the municipality is to represent each of its citizens against any public-private venture. The [AMHP] divided this community $70 \%$ in favor $30 \%$ against are favorable for an organization's mission or existence. Figure 3 shows the strongest alignment

based on the data we have gathered. However, I feel that communities in Chile are not prepared to challenge a project of this magnitude, be it mining, hydroelectric, etc. And the municipalities are not professionally equipped to protect the community or local surroundings, they do not have a technical team dedicated exclusively to evaluating projects and present observations."

This emergent hierarchy of power agrees with the three scales of power for water rights in Chile stated by Rojas Calderón (2014), from weak to strong: i.) communities, ii.) local organizations and local government (e.g., COM, MSJM), grassroots organizations and associations (e.g., NO-AM), iii.) and private surveillance boards composed of local agencies (SCM) and large private companies (AA, AES-GEN). Coincidentally, this partnership of private companies represents the proposed governing body of the upper basin of the Río de Maipo, where the primary control of water rights is controlled by these organizations de facto (Borgias and Bauer 2018).

\section{Alignment between Organizations (3CAA Analysis)}

Interpretation of organizational alignment is based on an analysis of third order convergence scores within the 3CAA and is facilitated by creating a convergence map (Figure 3), which shows interdependencies between aligning organizations. Overall, 3CAA scores - calculated by multiplying indirect influence scores (MDII), level of power $\left(\mathrm{Ri}^{*}\right)$ and convergence scores on project objectives (CAA, from the 2MAO developed by the research team, Appendix Table A2) - ranged from 2.1 to 22.5. Figure 3 graphically represents the strength of alignment, based on convergence scores, between the various AMHP organizations. A thick red link signifies the strongest alignment (18.5 to 22.5), a thick blue link signifies a strong alignment (14.4 to 18.4), a thin blue link signifies a moderate alignment (10.3 to 14.3), a thin grey link signifies a weak alignment (6.2 to 10.2), and a faint grey link signifies a very weak alignment (2.1 to 6.1$)$.

High convergence scores indicate a symbiotic alignment, where both influence and objectives exists between MMA and NO-AM. Interestingly, NO-AM indicated they have had minimal contact 
with MMA, and that they were not pleased with the ministry's capacity to handle the environmental evaluation of AMHP:

"The first time the country's highest political authority on the environment [MMA] received us allowed for a brief conversation. We were then told that they can't do much because they only have two inspectors for the metropolitan region, and the Alto Maipo project is a giant project. But millions of dollars in public resources are wasted in discussing tourist areas of interest, which will have been wasted if the Alto Maipo project comes into operation."

It is possible that the strong alignment between MMA and NO-AM emerged from a shared focus on environmental concerns, mitigated through Chilean regulation, primarily Environmental Law 19.300 and Water code 1981. As NO-AM mentions: "We asked them [MMA] to comply with the law [for environmental regulation, law 19.300 of 1994], which, even if it was not sufficient, was the law."

412 by a strong convergence between MMA and CONAF. This is not surprising, as these three 413 organizations have the mission to support ecosystem health and management, where CONAF upholds 414 the protection and conservation of forests, NO-AM seeks protection of the rivers of the Cajón del 415 Maipo and its surroundings, and MMA, seeks a more general equilibrium of natural Chilean ecosystems in Chile (Ministry of Environment 2020). Interestingly, these three organizations are not formal allies, even though our findings show that they align on many AMHP project objectives. A

418 reason for this hidden alignment is perhaps because state institutions must typically remain neutral per

419 Chilean law and regulation - ruling in relation to the project only within their technical competences 420 (Silva 2010).

A similar alignment was found to exist between NO-AM, CTCM, and COM, as they share the territorial and environmental consequences associated with the development of AMHP, leading them to have common interests. It is also possible to see a triumvirate alignment between AA, GDW and MMA, which could be expected, given their mission to protect and conserve water sources. AA and

425 DGA are organizations whose mission is based on water resources (drinking water supply, water quality, and water rights management), and the MMA (water protection and conservation of water, 
land and air), therefore, alignment is likely associated with a unified mission to care and protect inland water ecosystems.

While community - and municipal-level organizations show minimal alignment with the

430 larger private and state-level organizations, we see a moderate to strong connection between the SCM

431 and JVSM, and the other state organizations in charge of supporting environmental protection

432 (CONAF, MMA) and the Chilean Water Code (DGA). Despite having low-levels of power and high

433 levels of dependency on other organizations, MSJM and COM appear central in the alliance battle-

434 field.

It can be seen that AES-GEN has the weakest alignment with the rest of the organizations,

with all links being weak or very weak. The weakest of these alignments are from MSJM and COM, indicating they have both a low level of influence on AES-GEN activities as well as a minimal alignment on project objectives.

\section{Conflict between Organizations (3DAA Analysis)}

Interpretation of the conflict between organizations is based on an analysis of third-order divergence scores within the 3DAA and is facilitated by creating a divergence map, presented in

442 Figure 4, which shows interdependencies between conflicting organizations. Third order divergence 443 scores ranged from 0.8 to 13.2 , with a max divergence score about two times less than the top third 444 order convergence score (22.5). A thick red link signifies the strongest misalignment (10.8 to 13.2), a thick blue link signifies a strong misalignment ( 8.3 to 10.7), a thin blue link signifies a moderate misalignment (5.8 to 8.2), a thin grey link signifies a weak misalignment (3.3 to 5.7), and a faint grey link signifies a very weak misalignment (0.8 to 3.2 ).

This analysis shows a clear focal point of conflict on AES-GEN, in particular between

449 CONAF (10.2), MMA (10.7) and NO-AM (13.2). With a mission to halt construction of the AMHP, 450 and a moderate $\mathrm{Ri}^{*}$, it is expected that NO-AM would have the strongest divergence score (13.2) with 451 AES-GEN. However, it is MMA and CONAF that pose the most detrimental conflict for AES-GEN, 452 given their collective mission of environmental protection and stewardship along with the power to 453 derail the company's mission. Similarly, from analysis of indirect organizational influences, MMA had the largest level of power and lowest dependence on the other organizations, while AES-GEN had 
the largest dependence on the other organizations, as evidenced by their centrality in the conflict network (Figure 4). Finally, we see that SCM and JVSM have low levels of conflict, both with AES-

457 GEN as well as the other environmentally-focused organizations, despite having relatively highpower level scores Ri* (Figure 2).

459

\section{Net Distances between Objectives}

The graph of net distances between objectives, presented in Figure 5, offers insight on the relationship between objectives where organizations take the same position, whether for or against, based on their interconnectivity and strength of alignment or opposition. This analysis reveals groups of objectives between which there is strongest alignment (objectives with low net distances) or conflict (objectives with large net distances) (Godet 1994). This graph reveals the objectives for which organizations are most divergent relate to aspects of environmental protection, provision of water and energy services and community prosperity. This shows how AMHP potentially imposes a tension between the needs and benefits of providing energy and overall community prosperity, with the potentially detrimental effects on water availability and quality and environmental degradation. Conversely, the objectives with smaller net distances and thus greater alignment are those related to the social approval and financing of the project, together with social cohesion. This implies that social issues are less likely to drive conflict or alignment between organizations, and that the key battleground surrounds the impact on environment, water availability and water quality, which comes with a host of indirect societal, economic and environmental consequences. These results show the interconnected battlefield between organizational objectives, and how these objectives do not exist in isolation and thus must be managed thoughtfully to minimize conflict.

\section{DISCUSSION}

Findings from this study offer systems-level insights regarding organization power dynamics,

480 the presence of alliances and conflicts between organizations (addressing RQ1), whether perceived or 481 unperceived, and the objectives on which organizations align or misalign (addressing RQ2). This 
enables us to discuss core aspects of collaboration, communication, alignment and conflict mitigation

483 towards productive management of AMHP and the Río Maipo watershed (addressing RQ3).

Regarding RQ1 (alliance, conflicts, power dynamics), we see that the most powerful

stakeholder organizations are state agencies. However, despite state agencies having the greatest

influence on other organizations, whereby the management of water resources in Chile is the responsibility of many institutions (i.e., Directorate of Hydraulic Works (DOH), CONAF, and the

Ministry of Agriculture), the previously mentioned studies on Chilean Water law and water governance highlight weaknesses in institutional capacity to administer water law and manage multiorganization interests and conflicts, in particular the DGA's power to monitor and enforce water rights transactions (Bauer 2015; Bitran et al. 2014; Budds 2004; Roose and Panez 2020). The DGA representative reinforced this point:

"Firstly, our unit has to approve all the projects throughout Chile and this activity is done at our headquarters where we have only 5 people working. You see that the permit fee that they require is more than the installed capacity and there are also a lot more conditions ... There are emblematic cases that are more time consuming. The Law establishes that the DGA while it does not have all the antecedents cannot respond, that to the extent that you have a long line of reviews you go out of one and you get into another the main problem from the point of view of In view of time, it is the environmental evaluation ... if it does not have a favorable environmental evaluation, all permits are prohibited ... and when the environmental evaluation is finished they come to organizations, such as MSJM (Ri* 0.18$)$ or COM (0.09) are less able to promote their objectives.

505 Local organizations generally lack the necessary maturity or capacity to negotiate before large companies or institutions (Goodwin et al. 2006), despite an enthusiastic social-environmental dynamic that arise with the support of social network media (Twitter, Facebook, Instagram, etc.). This

508 immaturity limits their ability to advocate for their interests, and undermines a true IWRM program 509 (Donoso 2018; Hassing et al. 2009; Jusi 2013; Suárez et al. 2014; UNDP 2008). The 2005 Chilean 
510 Water Law also lacks support mechanisms and modalities through which to protect and support local

511 communities and organizations in response to their demands (Roose and Panez 2020).

512 Despite a formal regulatory framework to engage interests of local organizations, past

513 grassroots citizen action groups in Chile have had enormous impact on hydroelectric programs. For

514 example, the campaign "Rio Pueblo Sin Torres" (Rio Pueblo without Towers), was a highly

successful communication initiative that promoted awareness of the conflict between the community of Cochamó and the company Mediterráneo. Their Facebook page has over 53,000 followers (the town only has a population of 4,000) showing the significant diffusion and reach a local organization can have (Velásquez 2018). Another example is the organization 'Patagonia Sin Represas' (PSR -

519 Chilean Patagonia without Dams). PSR also used social networks as a tool to amass support, power and legitimacy with a structural change of the power, upscaling until the highest political levels in the country take notice (Romero Toledo 2014). Nevertheless, the strengthening of user organizations strongly depends on the existence of a legal framework that enables a diverse range of organizational participation in decision-making.

Regarding RQ2 (the objectives on which organizations align or misalign), our results show that the most powerful organizations are those who also align most on environmental objectives.

Private and community-based organizations who align with aspects of environmental protection find a favorable relationship with these organizations. As previously mentioned, our results revealed a general non-existence of 'alliance clusters'; that is, aligned organizations appeared, through analysis of secondary data and the interviews, to advocate for their mission separately with little to no cooperation to face opposing organizations. The only organizations that confirmed formal alliance were NO-AM and CTCM, where the other aligning organizations, such as DGA, SCM, AA, and JVSM, appear to act in isolation, maintaining a neutral or regulatory role based on the legal confines of the Chilean Water Code (BCN 2018). organization alignment, conflict, and influence, we address RQ3 (overall study implications) with

536 three overarching findings: i.) state agencies (MMA, DGA, CONAF) have the greatest power to 537 realize their organizational objectives, yet they often work in isolation and are limited in their power 
and capacity by the 2005 Chilean Water Law (that reformed a part of the 1981 Chilean Water Law) to

539 promote a true IWRM structure, ii.) large private companies have a greater capacity to achieve their

540 objectives than local community and grass-roots organizations, and iii.) the source of greatest conflict

541 centers around environmental objectives.

Recommendations for IWRM Policy and Practice in Chile

Based on the study findings, we propose facilitating positive synergies among aligned organizations by promoting collaboration between CONAF and NO-AM to do joint work with the

546 ME to leverage their power within the Chilean Water Law to uphold environmental standards and

547 impacts on water resource availability. This outcome could be achieved through an adjustment of

548 regulatory standards and communication protocols in Chile for megaprojects to better consider the environmental demands of all organizations, defining the control and regulation processes together with the increase in resources available for these types of environmental conflicts. Conjointly, it will be important to seek to minimize conflicts between organizations, in this case, between AES-GEN and the local community and governmental organizations affected by the project, through increased public and user participation and discussion (Borgias and Bauer 2018; Retamal et al. 2013; Larrain 554 2010)

The early formation of relationships and dialogue is key in minimizing conflicts between organizations. Past studies have shown that early alliances have more productive collaboration, establish more credibility in the local community, and are more effective at balancing collaborative initiatives against competitive interests (Hearld et al. 2012; Derakhshan, Turner and Mancini 2018;

559 Baharuddin et al. 2017). Indeed, numerous examples help us understand that an organization's

560 management, co-governance and social legitimacy are relevant concepts to consider in the success of

561 future hydroelectric projects in Chile and beyond (e.g., Birnbaum 2015; Marrewijk 2005; Sandström,

562 Crona and Bodin 2013). Similar to what we find in our study, this past work shows that in countries

563 like Chile, power is concentrated on government agencies, leaving a legal deficit in local

564 organizations to defend themselves against the impacts of megaprojects. NO-AM is an interesting

565 exception, given that they are a community organization established by local stakeholders who have 
economic resources as well as the professional and the international connections needed to engage in

567 this territorial defense. In other words, NO-AM has been able to privatize local defense, which is not

568 always possible for local community organizations. This is consistent with findings established by

569 Aliste and Stamm (2016), who state that in Chile the main social-environmental conflicts are concentrated in wealthier socioeconomic sectors, raising concerns about the exclusion of proper defense of rural and impoverished sectors of society. This lack of public support could be ameliorated with the help of international non-governmental organizations (iNGOs) that have expertise regarding international law (e.g., World Wildlife Fund and International union for Conservation of Nature)

574 (Eliantonio 2018; Barnes and van Laerhoven 2014), helping educate local organizations on best 575 practices to self-advocate and build their organization's legitimacy. It is important to understand that external organizational legitimacy (Drori and Honig 2013) or social legitimacy (Suchman 1995) is a perception or assumption developed by the observer, but it is always socially constructed, depending on what each group expects from the entity. Indeed, our study shows that social approval and alignment goes beyond legal requirements and authorizations, and are better understood from a systemic perspective, where local organizations that interact and are affected by the project have a voice and an agency to impact project outcomes. Overall, the mitigation of future water use conflicts between organizations, and improved program planning, implementation and management in subsequent hydroelectric projects in Chile, requires a refined legal framework and protocol for information exchange and capacity building. (Ricart and Clarimont 2015).

\section{Study Limitations \& Future Research}

There were some unavoidable issues with validity and generalizability resulting from the data collection and analysis activities.. Obtaining a rigorous representation of objectives and levels of influence between relevant AHMP organization was challenging, as it was not possible to interview organizational representatives from AA, MMA, SCM, and CONAF. We sought to circumvent this

590 issue with the responses from the other interviewees in conjunction with information extracted from

591 the secondary data sources, which included official information channels of each organization and the publicly available environmental impact evaluation. However, we recognize that a true representation of organizational influence on hydroelectric project success also requires consideration of individual 
stakeholders, such as electricity and water consumers, a task that is more difficult to accomplish and

595 evaluate with a MACTOR analysis. Excluding these types of stakeholder groups in this study

596 potentially resulted in an incomplete assessment of stakeholder impact on IWRM strategies for

597 AMHP.

598 Another study limitation relates to the transparency of information provided by the interviewed organizations, a common problem in both qualitative and quantitative studies. It is

600 possible that the organizational representatives interviewed neglected to openly reveal their plans,

601 strategies and objectives, as well as the type of relationship they may have with respect to the other

602 organizations. In addition, there is a risk that the information delivered is not completely true or that

603 the same organizations have a different vision with respect to the topics consulted. As mentioned

604 previously, the research team sought to mitigate errors from false information by comparing data

605 across interviewees and secondary data sources.

A final limitation relates to subjectivity imposed within MACTOR analyses conducted by the researcher team. Although our analysis was carried out with a multidisciplinary team composed of professionals with different backgrounds, degrees, and perspectives, there is an invariable potential

609 for subjectivity, whereby the various forms of information used to perform the MACTOR analysis

610 could have been interpreted differently. The research team sought to minimize subjectivity by

611 gathering and contrasting various forms of secondary data, as well as the interview transcriptions to cross-validate the MACTOR outputs

Despite these limitations, we believe the MACTOR approach, as applied within the multi-step

614 process presented here, provided useful insight into the interdependencies and associated alliances and

615 conflicts between key project organizations of complex and large hydropower projects in general and

616 AMHP in particular. This process could be improved upon in future studies to limit subjectivity, and

617 improve insight on the interactions between organizations and individual stakeholders and their

618 impact on IWRM strategies and hydroelectric project success. Such improvements to the

619 methodology could include: i) Further engagement and discourse between organizations to modify

620 MACTOR inputs and collaboratively evaluate outputs throughout the various stages of project

621 planning, implementation and management, ii) Following-up this study in five to ten years to 
622 compare and contrast findings with any landmark project outcomes related to AMHP management

623 and coordination between organizations, and iii) complimenting MACTOR insights from other

624 systems analyses, such as social network analysis (SNA), to gain a deeper understanding on alignment

625 and conflict based on the flow of communication and knowledge between organizations and

626 individual stakeholders.

\section{CONCLUSIONS}

628 This study used a mixed-method process culminating with the MACTOR approach to identify

629 and evaluate the interconnected drivers of alignment and conflict between 11 key organizations

630 connected with the Alto Maipo Hydroelectric Project in Chile. Findings from this analysis revealed

631 underutilized synergies between siloed state organizations, and the centering of conflicts or alignment

632 around environmental protection and resource use. It was also seen that while state agencies have the

633 greatest power to realize their organizational objectives with the Rio Maipo watershed, they remain

634 limited in their power and capacity to realize these objectives by existing legal frameworks. Finally,

635 the study revealed a substantial power gap between state agencies and local organizations. These

636 findings point to the need for the development or refinement of policies and legal frameworks that

637 foster connection and collaboration between aligned, yet currently, hermetic organizations to uphold

638 environmental standards and impacts on water resource availability. Capacity building by local non-

639 profits or iNGOs for local community and governmental organizations could help narrow the power

640 gap with state agencies by promoting community-level advocacy for more productive negotiation and

641 increased organizational legitimacy.

642 The MACTOR approach, as applied within the multi-step process presented here, provided a

643 powerful way to visualize and evaluate the interconnected drivers of alignment or conflict between

644 organizations involved with or affected by hydroelectric projects. However, future studies would

645 benefit from a more iterative and reflective engagement of organizational representatives in the

646 process throughout the implementation and early stages of project management. Future hydroelectric

647 projects in Chile, and beyond, could benefit from the early application of this process as a way to 
engage relevant organizations in a thoughtful discussion of managing objectives to mitigate conflict

649 and promote alignment towards a common agenda for sustainable water resource management..

\section{DATA AVAILABILITY STATEMENT}

651 Some or all data, models, or code that support the findings of this study are available from the

652

corresponding author upon reasonable request. This includes:

- A coarse summary of qualitative analysis of secondary data and interview transcripts

- The complete MACTOR analyses within a LIPSOR MACTOR software file (xml format)

\section{ACKNOWLEDGEMENTS}

We would like to thank the interviewees - and their respective organizations - who

participated in this study for their invaluable insights that underpinned the validity and relevance of the study findings. This research did not receive any specific grant from funding agencies in the public, commercial, or not-for-profit sectors.

\section{REFERENCES}

Aliste, E., and Stamm, C. (2016) "Hacia una geografía de los conflictos socioambientales en Santiago de Chile: lecturas para una ecología pol-itica del territorio". Revista de Estudios Sociales, 55, 45-62

Ansar, A., Flyvbjerg, B., Budzier, A., and Lunn, D. (2014). "Should we build more large dams? The actual costs of hydropower megaproject development." Energy Policy, 69, 43-56.

Arcade, J., Godet, M., Meunier, F., and Roubelat, F. (2009). Structural analysis with the MICMAC method \& Actors' strategy with MACTOR method. Futures Research Methodology. The Millennium Project: Futures Research Methodolog.

Baharuddin, H., Che Ibrahim, C., Costello, S., and Wilkinson, S. (2017). Managing stakeholders through alliances: a case study of a megaproject in New Zealand. Management, Procurement and Law, 170, 151-160.

Barnes, C., and van Laerhoven, F. (2014). Making it last? Analysing the role of NGO interventions in the development of institutions for durable collective action in Indian community forestry. Environmental Science \& Policy, 53, 192-205.

Bauer, C. J. (2009). "Dams and Markets: Rivers and Electric Power in Chile." NATURAL RESOURCES JOURNAL, 49, 71.

Bauer, C. J. (2015). "Water Conflicts and Entrenched Governance Problems in Chile's Market Model." 8(2), 26.

BCN. (2018). "Codigo de Aguas, Derecho de Aprovechamiento de aguas, Aguas/Legislacion/Chile, Ley: 21064." Biblioteca de Congreso Nacional de Chile/BCN.

Bettencourt, R. (2010). "Strategic prospective for the implementation of employment policies in the Azores." Technological Forecasting and Social Change, 77(9), 1566-1574.

Birnbaum, S. (2015). Environmental co-governance, legitimacy, and the quest for compliance: when and why is stakeholder participation desirable? Journal of Environmental Policy and Planning, 18(3), 306-323.

Bitran, E., Rivera, P., and Villena, M. J. (2014). "Water management problems in the Copiapó Basin, Chile: markets, severe scarcity and the regulator." Water Policy, 16(5), 844-863. 
Blanco, V. (1997). "DE LOS DERECHOS DE AGUAS. EL CASO CHILENO.” REVISTA CHILENA DE DERECHO, 28.

Borgias, S., and Bauer, C. J. (2018). "Trajectory of a divided river basin: law, conflict, and cooperation along Chile's Maipo River." Water Policy, 20(1), 127-145.

Bourne, L., and Walker, D. H. T. (2005). "Visualising and mapping stakeholder influence." Management Decision, 43(5), 649-660.

Bourne, L., and Walker, D. H. T. (2006). "Visualizing Stakeholder Influence - Two Australian Examples." Project Management Journal, 37(1), 5-21.

Budds, J. (2004). "POWER, NATURE AND NEOLIBERALISM: THE POLITICAL ECOLOGY OF WATER IN CHILE.” Singapore Journal of Tropical Geography, 25(3), 322-342.

Chinowsky, P., Diekmann, J., and Galotti, V. (2008). "Social Network Model of Construction." Journal of Construction Engineering and Management, 134(10), 804-812.

CIPER. (2011). “Convenio Entre Aguas Andinas S.A. y Aes Gener S.A.” Centro de Investigación Periodística.

Correa-Parra, J., Vergara-Perucich, J. F., and Aguirre-Nuñez, C. (2020). "Water Privatization and Inequality: Gini Coefficient for Water Resources in Chile." Water, 12(12), 3369.

Dashwood, H. (2012). The Rise of the Global Corporate Social Responsibility: Mining and the Spread of Global Norms. Cambridge University Press.

Davis, M. D. (2007). "Integrated Water Resource Management and Water Sharing." Journal of Water Resources Planning and Management, 133(5), 427-445.

Derakhshan, R., Turner, R., Mancini, M. (2019). Project governance and stakeholders: a literature review. International Journal of Project Management, 37, 98-116.

Donoso, G. (Ed.). (2018). Water Policy in Chile. Global Issues in Water Policy, Springer International Publishing, Cham.

Drori, I., and Honig, B. (2013). "A Process Model of Internal and External Legitimacy.” Organization Studies, 34(3), 345-376.

El Mercurio. (2020). "AES Gener pide a CNE a retrasar al tercer trimestre de 2021 interconexión de Alto Maipo." El Mercurio, Santiago de Chile.

Eliantonio, M. (2018). The role of NGOs in environmental implementation conflicts: 'stuck in the middle' between infringement proceedings and preliminary rulings? Journal of European Integration. 40(6) 753-767.

EPITA. (2010). La Prospectiva - MACTOR Software.

de Figueiredo Porto, C. A., Marques, E., and Santos, A. B. A. (2010). "Prospective in Brazil: The power to build the future." Technological Forecasting and Social Change, 77(9), 1550-1558.

Fiori, C., and Kovaka, M. (2005). "Defining Megaprojects: Learning from Construction at the Edge of Experience." Construction Research Congress 2005, American Society of Civil Engineers, San Diego, California, United States, 1-10.

Flyvbjerg, B. (2014). "What you Should Know about Megaprojects and Why: An Overview." Project Management Journal, 45(2), 6-19.

Flyvbjerg, B., Bruzelius, N., and Rothengatter, W. (2003). Megaprojects and Risk: An Anatomy of Ambition. Cambridge University Press, The Pitt Building, Trumpington Street, Cambridge CB2 1RP, United Kingdom.

Freeman, R. E., Harrison, J. S., Wicks, A. C., Parmar, B. L., and De Colle, S. (2010). Stakeholder Theory: The State of the Art. Cambridge University Press, The Edinburgh Building, Cambridge CB2 8RU, UK.

Gallego-Ayala, J., and Juízo, D. (2014). “Integrating Stakeholders' Preferences into Water Resources Management Planning in the Incomati River Basin.” Water Resources Management, 28(2), $527-540$.

Godet, M. (1976). "Scenarios of air transport development to 1990 by SMIC 74-A new cross-impact method." Technological forecasting and social change, 9(3), 279-288.

Godet, M. (1991). "Actors' moves and strategies: The mactor method." Futures, 23(6), 605-622.

Godet, M. (1994). From anticipation to action: a handbook of strategic prospective. Future-oriented studies, UNESCO Pub, Paris, France.

Godet, M. (2007). Manuel de prospective stratégique - Tome 2 - L'Art et la méthode. Dunod, Paris, France. 
Goodwin, P., Jorde, K., Meier, C., and Parra, O. (2006). "Minimizing environmental impacts of hydropower development: transferring lessons from past projects to a proposed strategy for Chile." Journal of Hydroinformatics, 8(4), 253-270.

Grigg, N. S. (2016). "Systems Thinking as an IWRM Tool." Integrated Water Resource Management, Palgrave Macmillan UK, London, 119-138.

Hassing, J., Ipsen, N., Clausen, T. J., Larsen, H., and Lindgaard-Jørgensen, P. (2009). "Integrated Water Resources Management (IWRM) in Action." 22.

Hearld, L., Alexander, J., Beich, J., Mittler, J. and O'Hara, J. (2012). "Barriers and Strategies to Align Stakeholders in Healthcare Alliances". The American Journal of Managed Care, 18(6) s148s156.

Ignatius Teye Buertey, J. (2016). "Stakeholder Management on Construction Projects: A Key Indicator for Project Success." American Journal of Civil Engineering, 4(4), 117.

INDH. (2012). "Mapa de Conflictos Socioambientales en Chile." Instituto Nacional de Derechos Humanos, <https://mapaconflictos.indh.cl/\#/conflicto/12420> (Mar. 13, 2018).

INE. (2018). "SÍNTESIS DE RESULTADOS CENSO 2017." Instituto Nacional de Estadisticas.

Jergeas, G. F., Williamson, E., Skulmoski, G. J., and Thomas, J. L. (2000). "Stakeholder Management on Construction Projects." AACE International Transactions, PM.12, 12.1-12.6.

Jusi, S. (2013). Integrated water resources management (IWRM) approach in water governance in Lao PDR: cases of hydropower and irrigation. Acta Universitatis Tamperensis, Tampere University Press, Tampere.

Latta, A. P. (2007). "Citizenship and the Politics of Nature: The Case of Chile’s Alto Bío Bío." Citizenship Studies, 11(3), 229-246.

Maher, R. (2019). "Pragmatic community resistance within new indigenous ruralities: Lessons from a failed hydropower dam in Chile." Journal of Rural Studies, 68, 63-74.

Marrewijk, A. (2005). Strategies of Cooperation: Control and Commitment in Mega-Projects. Management, 8(4), 89-104.

Marrewijk, A., Clegg, S., Pitsis, T., Veenswijk, M. (2008). Managing Public-Private Megaprojects: Paradoxes, Complexity and Project Design. International Journal of Project Management, 26(6), 591-600.

Merino, M. E., and Bello, M. E. (2014). "Discourse Coalitions in the Controversy around the HydroAysen Project in the Patagonia Region of Chile." International Journal of Social Science Studies, 2(3), 1-11.

Ministry of Environment. (2020). "Estructura Organizacional." Ministerio del Medio Ambiente, Chile. Molle, F., and Wester, P. (2009). "River Basin Trajectories." 327.

Newcombe, R. (2003). "From client to project stakeholders: a stakeholder mapping approach." Construction Management and Economics, 21(8), 841-848.

Palinkas, L. A., Horwitz, S. M., Green, C. A., Wisdom, J. P., Duan, N., and Hoagwood, K. (2015). "Purposeful Sampling for Qualitative Data Collection and Analysis in Mixed Method Implementation Research." Administration and Policy in Mental Health and Mental Health Services Research, 42(5), 533-544.

Remington, K., and Pollack, J. (2008). Tools for Complex Projects. Routledge, Milton Park, Abingdon, Oxfordshire.

Ricart, S., and Clarimont, S. (2015). Modelling the links between irrigation, ecosystem services and rural development in pursuit of social legitimacy: Results from a territorial analysis of Neste System (Hautes-Pyrénées, France). Journal of Rural Studies. 43, 1-12.

Rojas Calderón, C. (2014). “Autogestión y Autorregulación regulada de las aguas: Organizaciones de usuario de aguas (OUA) y Juntas de vigilancia de ríos." Ius et Praxis, 20(1), 123-162.

Romero Toledo, H. (2014). "Ecología política y represas: elementos para el análisis del Proyecto HidroAysén en la Patagonia chilena." Revista de geografía Norte Grande, (57), 161-175.

Roose, I., and Panez, A. (2020). "Social Innovations as A Response to Dispossession: Community Water Management in View of Socio-Metabolic Rift in Chile." Water, 12(2), 566.

Rowley, T. J. (1997). "Moving Beyond Dyadic Ties: A Network Theory of Stakeholder Influences." Academy of Management Review, 22(4), 887-910 
Rowley, T. J., and Moldoveanu, M. (2003). "When Will Stakeholder Groups Act? An Interest- and Identity-Based Model of Stakeholder Group Mobilization.” The Academy of Management Review, 28(2), 204.

Sandström, A., Croma, B., Bodin, Ö. (2013). Legitimacy in Co-Management: The Impact of Preexisting Structures, Social Networks and Governance Strategies. Environmental Policy and Governance, 24, 60-76.

SEA. (2018). "Comisión de Evaluación Ambiental de la Región Metropolitana." Servicio de Evaluación, Chile.

SEIA. (2007). "Forma de Presentación: Estudio de Impacto Ambiental." Sistema de Evaluación de Impacto Ambiental, Chile.

Silva, P. (2010). En el nombre de la razón. Tecnócratas y política en Chile. Ediciones UDP. Santiago, Chile.

Sovacool, B. K., and Bulan, L. C. (2011). "Behind an ambitious megaproject in Asia: The history and implications of the Bakun hydroelectric dam in Borneo." Energy Policy, 39(9), 4842-4859.

Suárez, F., Muñoz, J., Fernández, B., Dorsaz, J.-M., Hunter, C., Karavitis, C., and Gironás, J. (2014). "Integrated Water Resource Management and Energy Requirements for Water Supply in the Copiapó River Basin, Chile.” Water, 6(9), 2590-2613.

Suchman, M. C. (1995). "Managing Legitimacy: Strategic and Institutional Approaches.” The Academy of Management Review, 20(3), 571.

Torrealba, P. (2018). "Alto Maipo: Financistas internacionales llegan a Chile para evaluar su participación." El Murcurio, Santiago de Chile.

UNDP. (2008). "Conflict Resolution and negotiation Skills for Integrated Water Resources Management." Cap-Net, United Nations Development Programme.

United Nations, Department of Economic and Social Affairs, and Population Division. (2019). World urbanization prospects: the 2018 revision.

Velásquez, F. (2018). "El movimiento del Río Puelo que dejó sin permiso ambiental a la hidroeléctrica Mediterráneo." diarioUchile, Santiago de Chile.

Vivanco-Aranda, M., Mojica, F. J., and Martínez-Cordero, F. J. (2011). "Foresight analysis of tilapia supply chains (Sistema Producto) in four states in Mexico: Scenarios and strategies for 2018." Technological Forecasting and Social Change, 78(3), 481-497.

Yang, R. J., and Shen, G. Q. P. (2015). "Framework for Stakeholder Management in Construction Projects." Journal of Management in Engineering, 31(4), 04014064.

Werkheiser, I., and Piso, Z. (2015). "People Work to Sustain Systems: A Framework for Understanding Sustainability." Journal of Water Resources Planning and Management, 141(12). 
TABLES

834 Table 1. A summary of the organizations included in this study and the secondary data used to

835 represent these organizations. Organization names are abbreviated in parenthesis for later use in data

836 visualization (Figures 2 through 4). Where appropriate, we use the Spanish abbreviations used in

837 Chile, with full names translated to English. More information on the secondary data sources for

838 each organization can be found in the Appendix using the provided source numbers.

\begin{tabular}{|c|c|c|c|}
\hline Organization & Role & Org. Type & $\begin{array}{l}\text { Secondary Data } \\
\text { Sources }\end{array}$ \\
\hline $\begin{array}{l}\text { AES-GENER } \\
\text { (AES-GEN) }\end{array}$ & $\begin{array}{l}\text { Chilean electric power company in charge } \\
\text { of implementing and managing the } \\
\text { AMHP. }\end{array}$ & Private & $13,14,15$ \\
\hline Aguas Andinas (AA) & Chilean company of sanitary services. & Private & 1,2 \\
\hline $\begin{array}{l}\text { General Directorate of } \\
\text { Water (DGA) }\end{array}$ & $\begin{array}{l}\text { State Agency that is responsible for } \\
\text { promoting the management and } \\
\text { administration of water resources. }\end{array}$ & $\begin{array}{l}\text { National } \\
\text { Government }\end{array}$ & $10,11,12$ \\
\hline $\begin{array}{l}\text { Ministry of the } \\
\text { Environment (MMA) }\end{array}$ & $\begin{array}{l}\text { Ministry in charge of collaborating in the } \\
\text { design and application of policies, plans } \\
\text { and programs in environmental matters. }\end{array}$ & $\begin{array}{l}\text { Regional } \\
\text { Government }\end{array}$ & $7,8,9$ \\
\hline $\begin{array}{l}\text { National Forest } \\
\text { Corporation (CONAF) }\end{array}$ & $\begin{array}{l}\text { Dependent entity of the Ministry of } \\
\text { Agriculture, in charge of administering } \\
\text { Chile's forest policy and promoting the } \\
\text { development of the sector. }\end{array}$ & $\begin{array}{l}\text { Regional } \\
\text { Government }\end{array}$ & 5,6 \\
\hline $\begin{array}{l}\text { Communal Union of } \\
\text { the Neighborhood } \\
\text { Board of San José de } \\
\text { Maipo (COM) }\end{array}$ & $\begin{array}{l}\text { Community organization maintained by } \\
\text { the Neighborhood Boards of San José de } \\
\text { Maipo }\end{array}$ & $\begin{array}{c}\text { Local } \\
\text { Organization }\end{array}$ & $\begin{array}{l}\text { No published } \\
\text { secondary data } \\
\text { available }\end{array}$ \\
\hline $\begin{array}{l}\text { No Alto Maipo (NO- } \\
\text { AM) }\end{array}$ & $\begin{array}{l}\text { Organization that oversees the protection } \\
\text { of the valleys and rivers of the Cajón del } \\
\text { Maipo watershed }\end{array}$ & $\begin{array}{l}\text { Social- } \\
\text { environmental } \\
\text { NGO }\end{array}$ & 18,19 \\
\hline $\begin{array}{l}\text { Maipo Canal Society } \\
\text { (SCM) }\end{array}$ & $\begin{array}{l}\text { Non-profit organization of private law, } \\
\text { responsible for the extraction and } \\
\text { distribution of water from the Maipo } \\
\text { River. }\end{array}$ & $\begin{array}{l}\text { Irrigation } \\
\text { Organization }\end{array}$ & 3,4 \\
\hline $\begin{array}{l}\text { Maipo Surveillance } \\
\text { Board (JVSM) }\end{array}$ & $\begin{array}{l}\text { Non-profit entity of private law, which } \\
\text { exercises the action granted by the } \\
\text { Chilean Water Code. Administers and } \\
\text { distributes water to those who have their } \\
\text { associated rights. }\end{array}$ & River organization & $\begin{array}{l}\text { No published } \\
\text { secondary data } \\
\text { available }\end{array}$ \\
\hline
\end{tabular}




\begin{tabular}{l|l|c|c}
\hline $\begin{array}{l}\text { Municipality of San } \\
\text { José de Maipo } \\
\text { (MSJM) }\end{array}$ & $\begin{array}{l}\text { Autonomous corporation, in charge of the } \\
\text { administration of the San José de Maipo } \\
\text { commune. }\end{array}$ & $\begin{array}{c}\text { Municipal } \\
\text { government }\end{array}$ & 16,17 \\
\hline $\begin{array}{l}\text { Chamber of Tourism } \\
\text { of the Cajón del } \\
\text { Maipo (CTCM) }\end{array}$ & $\begin{array}{l}\text { Trade association, responsible for the } \\
\text { promotion of tourism in the region of } \\
\text { Cajón del Maipo. }\end{array}$ & $\begin{array}{c}\text { Local } \\
\text { Organization }\end{array}$ & 20,21 \\
\hline
\end{tabular}

Table 2. Challenges and associated objectives from coded interview transcriptions, with parenthetical 842 objective abbreviations used in analyses shown in Figure 5.

\begin{tabular}{|c|c|c|}
\hline Challenge & Objective & Definition of Objective \\
\hline $\begin{array}{l}\text { Potential for high } \\
\text { environmental impact }\end{array}$ & $\begin{array}{l}\text { Protect the Environment } \\
\text { (Pro. Env.) }\end{array}$ & $\begin{array}{l}\text { Strengthen protection and mitigation measures for } \\
\text { impacts on the environment }\end{array}$ \\
\hline Social division & $\begin{array}{l}\text { Social Cohesion } \\
\quad \text { (Soc. Coh.) }\end{array}$ & $\begin{array}{l}\text { Maintain the interconnection and communication of } \\
\text { neighbors and communities }\end{array}$ \\
\hline $\begin{array}{l}\text { Issues with energy } \\
\text { availability }\end{array}$ & $\begin{array}{c}\text { Increasing the Supply of Renewable } \\
\text { Energy } \\
\text { (Ren. Ene.) }\end{array}$ & Growth in the supply of renewable energy \\
\hline $\begin{array}{l}\text { Issues with water } \\
\text { availability }\end{array}$ & $\begin{array}{l}\text { Availability of Water Resources } \\
\text { (Wat. Ava.) }\end{array}$ & $\begin{array}{l}\text { Ensure the availability, correct use and distribution of } \\
\text { water resources }\end{array}$ \\
\hline $\begin{array}{l}\text { Detrimental effects on } \\
\text { water quality }\end{array}$ & River Water Quality (Wat. Qual.) & Strengthen the monitoring of water status. \\
\hline Impacts on tourism & $\begin{array}{l}\text { Protection of Tourist Areas } \\
\text { (Pro. Tour.) }\end{array}$ & $\begin{array}{l}\text { Protection and conservation of areas for sustainable } \\
\text { tourism, ensuring the non-intervention of tourist areas. }\end{array}$ \\
\hline $\begin{array}{l}\text { Detrimental impacts on } \\
\text { the quality of } \\
\text { community life }\end{array}$ & $\begin{array}{l}\text { Local Community Prosperity } \\
\text { (Com. Pro.) }\end{array}$ & $\begin{array}{l}\text { Promote the economic prosperity and success of near-by } \\
\text { communities. }\end{array}$ \\
\hline $\begin{array}{l}\text { Initial Capital } \\
\text { Investment of Project }\end{array}$ & $\begin{array}{l}\text { Financing of Project } \\
\text { (Pro. Fin.) }\end{array}$ & $\begin{array}{l}\text { Ensure investment partners for the financing and } \\
\text { development of the project. }\end{array}$ \\
\hline $\begin{array}{l}\text { Potential for social } \\
\text { upheaval }\end{array}$ & $\begin{array}{l}\text { Social Approval } \\
\text { (Soc. App.) }\end{array}$ & $\begin{array}{l}\text { Obtain the approval of the communities and society for } \\
\text { the development and operation of the project. }\end{array}$ \\
\hline
\end{tabular}




\section{FIGURE CAPTIONS}

Figure 1. Overview of research activities, methods and outputs

849 Figure 2. Influence map for MDII, with $\mathrm{Ri}^{*}$ presented in table to the right. Direct and Indirect

850 influence scores normalized with max 90 (MMA), min 15 (COM). Dependence normalized with max 90 (AES-GEN) and min 36 (MMA).

852

Figure 3. Third-order convergence graph, showing the level of alignment between the various AMHP organizations; thick red link: strongest (18.5 to 22.5$)$, thick blue link: strong (14.4 to 18.4 ), thin blue link: moderate influence (10.3 to 14.3$)$, thin grey link: weak (6.2 to 10.2$)$, faint grey link: very weak (2.1 to 6.1). Score ranges (i.e., strongest or weak) are designated by the equal division of the total range of scores.

Figure 4. Third-order graph of divergence, showing the level of misalignment or conflict between the various AMHP organizations; thick red link: strongest (10.8 to 13.2), thick blue link: strong ( 8.3 to 10.7), thin blue link: moderate influence (5.8 to 8.2), thin grey link: weak (3.3 to 5.7), faint grey link: very weak ( 0.8 to 3.2$)$. Score ranges (i.e., strongest or weak) are designated by the equal division of

863 the total range of scores.

865 Figure 5. Graph of net distances between objectives; thick red link: Largest net distance (23 to 26),

866 thick blue link: Large net distance (17.5 to 23), thin blue link: mod (6 to 17.5), thin grey link: weak (0 867 to 5.5), faint grey link: Shortest net distance (-8.5 to 0$)$ 


\section{APPENDIX}

\section{MACTOR Mathematics}

Equations $1-4$ present mathematical operations used in evaluation of an organization's power (eq 1), competition (eq 2), convergence and divergence (eq 3), and net distance of objectives (eq 4)

\section{Matrix of Direct and Indirect Influences (MDII):}

Where,

$$
[M D I I]_{i j}=[M D I]_{i j}+\operatorname{LMin}\left([M D I]_{i j},[M D I]_{i k}\right)
$$

$[M D I I]_{i j}$ is the combined direct and indirect influence organization $i$ has on organization $j$.

$[M D I]_{i j}$ is the direct influence organization $i$ has on organization $j$ from the MDI

$\Sigma M i n\left([\boldsymbol{M D I}]_{i j},[\boldsymbol{M D I}]_{i k}\right)$ is the sum of all indirect influences actor i exerts on actor $j$, and which flow through an intermediary actor $k$; where this indirect interaction is kept 'second order' - that is, flowing only with one intermediary actor at a time (Godet 1991)

Evaluation of relative organizations' level of power $\left(R i^{*}\right)$ :

$$
\begin{gathered}
R i=\left[\left(I i-[\mathbf{M D I I}]_{i i}\right) / S\right] *[I i /(I i+D i)] \\
R i^{*}=n * R i / \Sigma R i
\end{gathered}
$$

Where,

$R i$ is an organization's competitiveness score

$R i^{*}$ is the normalized power score for each organization

$\left(I_{i}-[\mathrm{MDII}]_{\mathrm{ii}}\right)$ is the organization's 'maneuver range, in other words its net direct and indirect influence (Ii) minus its retroaction or vulnerability from actions they take indirectly feeding back to influence them (MDII)ii

$S=\Sigma i I i=\Sigma i D i$ factor for normalizing the maneuver range

$\mathrm{Ii} /(\mathrm{Ii}+\mathrm{Di})$ allowing a relative integration of organizations' influence and dependence in the equation.

$\Sigma R i$ is the sum of competitive scores

$n$ is the number of organizations

Third order evaluation of convergence (3CAA) and divergence (3DAA):

$$
\text { If }\left([\mathbf{3 M O A}]_{i k} *[\mathbf{3 M O A}]_{j k}\right)>0(\text { for } 3 C A A) \text { or }<0(\text { for } 3 D A A)
$$

$$
\text { Then }[3 C A A \text { or } 3 D A A]_{i j}=1 / 2 x\left(\left|[\mathbf{3 M O A}]_{i k}\right|+\left|[\mathbf{3 M O A}]_{j k}\right|\right)
$$

Where:

$$
\text { Else }[3 C A A \text { or } 3 D A A]_{i j}=0
$$

$$
[3 M O A]=R_{i}^{*} *[2 M O A]_{i j}
$$

\section{Distance on objectives:}




$$
\text { If }\left(\left([\mathbf{2 M O A}]_{i k} *[\mathbf{2 M O A}]_{j k}\right)>0(\text { for } 3 C A A) \text { or }<0(\text { for } 3 D A A)\right.
$$

$$
\begin{aligned}
& \text { Then }[\mathbf{2 C A A} \text { or } 2 \mathrm{DAA}]_{i j}=1 / 2 *\left(\left|[\mathbf{2 M O A}]_{i k}\right|+\left|[\mathbf{2 M O A}]_{j k}\right|\right) \\
& \text { Else }[2 C A A \text { or } 2 D A A]_{i j}=0
\end{aligned}
$$$$
[2 M O O] i j=[2 C A A] i j-[2 D A A] i j
$$

\section{Secondary Data Sources (from Table 1)}

1. https://www.aguasandinasinversionistas.cl/es/quienes-somos/nuestro-proposito

2. https://www.aguasandinasinversionistas.cl/ /media/Files/A/Aguas-IR-v2/annualreports/es/190626-reporte-integrado-aa2018.pdf

3. https://www.scmaipo.cl/canalistas/

4. https://www.scmaipo.cl/canalistas/wp-content/uploads/2019/04/Boletin_Gota-a-gota_N1.pdf

5. https://www.conaf.cl

6. https://www.conaf.cl/cms/editorweb/institucional/CUENTA-PUBLICA-CONAF2018-CONAPORTES-COSOC.pdf

7. https://mma.gob.cl

8. https://mma.gob.cl/wp-content/uploads/2018/03/Estrategia_Nac_Biodiv_2017_30.pdf

9. https://mma.gob.cl/wp-content/uploads/2018/03/Informe-Final-Encuesta-Nacional-de-MedioAmbiente-2018.pdf

10. https://dga.mop.gob.cl/Paginas/default.aspx

11. https://dga.mop.gob.cl/legistlacionynormas/Legislacin\%20y\%20Normas/LEY-21064_27ENE-2018.pdf

12. https://dga.mop.gob.cl/acercadeladga/informesgestion/Informes\%20de\%20gestin/BGI_DGA_ 2017.pdf

13. https://www.aesgener.cl/\#hello

14. https://conocealtomaipo.cl

15. https://www.aesgener.cl/wp-content/themes/aes_gener/pdfs/Politica-de-Vinculacion-yRelacionamiento-con-comunidades.pdf

16. https://www.sanjosedemaipo.cl

17. https://www.sanjosedemaipo.cl/gestion/direccion-de-desarrollo-comunitario/

18. http://www.chilesustentable.net/tag/no-alto-maipo/

19. https://www.facebook.com/NoAlProyectoAltoMaipo/

20. https://cajondelmaipochile.cl

21. https://www.facebook.com/cctsjm/

Table A1. Matrix of Direct Influence (MDI) between AMHP organizations, defined by research team

\begin{tabular}{|c|c|c|c|c|c|c|c|c|c|c|c|}
\hline & AES-GEN & AA & SCM & DGA & MMA & CONAF & CTCM & NO-AM & MSJM & COM & JVSM \\
\hline AES-GEN & 0 & 1 & 1 & 1 & 1 & 1 & 3 & 3 & 2 & 2 & 2 \\
\hline AA & 3 & 0 & 2 & 1 & 0 & 0 & 1 & 1 & 3 & 0 & 2 \\
\hline SCM & 2 & 3 & 0 & 1 & 0 & 0 & 0 & 1 & 1 & 0 & 2 \\
\hline DGA & 3 & 1 & 1 & 0 & 1 & 1 & 1 & 3 & 1 & 1 & 1 \\
\hline MMA & 2 & 1 & 1 & 1 & 0 & 1 & 3 & 3 & 2 & 1 & 1 \\
\hline CONAF & 2 & 1 & 1 & 0 & 1 & 0 & 2 & 3 & 1 & 1 & 0 \\
\hline CTCM & 2 & 0 & 0 & 0 & 0 & 1 & 0 & 3 & 2 & 0 & 0 \\
\hline NO-AM & 2 & 1 & 1 & 1 & 1 & 1 & 3 & 0 & 1 & 0 & 1 \\
\hline
\end{tabular}




\begin{tabular}{|c|c|c|c|c|c|c|c|c|c|c|c|}
\hline MSJM & 1 & 0 & 0 & 0 & 0 & 0 & 1 & 1 & 2 & 4 & 0 \\
\hline COM & 1 & 0 & 0 & 0 & 0 & 0 & 0 & 0 & 2 & 0 & 0 \\
\hline JVSM & 2 & 2 & 2 & 1 & 1 & 0 & 0 & 1 & 0 & 0 & 0 \\
\hline
\end{tabular}

Table A2. Matrix of AMHP organization position within the battlefield of objectives (2MAO), as defined by the research team

\begin{tabular}{|c|c|c|c|c|c|c|c|c|c|}
\hline & Pro. Evn. & Soc. Coh. & Ren. Ene. & Wat. Ava. & Wat. Qual. & Pro. Tour. & Com. Pro. & Pro. Fin. & Soc. App \\
\hline AES-GEN & 0 & 1 & 1 & 1 & 1 & 1 & 3 & 3 & 2 \\
\hline AA & 3 & 0 & 2 & 1 & 0 & 0 & 1 & 1 & 3 \\
\hline SCM & 2 & 3 & 0 & 1 & 0 & 0 & 0 & 1 & 1 \\
\hline DGA & 3 & 1 & 1 & 0 & 1 & 1 & 1 & 3 & 1 \\
\hline MMA & 2 & 1 & 1 & 1 & 0 & 1 & 3 & 3 & 2 \\
\hline CONAF & 2 & 1 & 1 & 0 & 1 & 0 & 2 & 3 & 1 \\
\hline CTCM & 2 & 0 & 0 & 0 & 0 & 1 & 0 & 3 & 2 \\
\hline NO-AM & 2 & 1 & 1 & 1 & 1 & 1 & 3 & 0 & 1 \\
\hline MSJM & 1 & 0 & 0 & 0 & 0 & 0 & 1 & 1 & 2 \\
\hline COM & 1 & 0 & 0 & 0 & 0 & 0 & 0 & 0 & 2 \\
\hline JVSM & 2 & 2 & 2 & 1 & 1 & 0 & 0 & 1 & 0 \\
\hline
\end{tabular}

Pro. Env.: Protect the Environment; Soc. Coh.: Promote Social Cohesion; Ren. Ene.: Increase the Supply of Renewable Energy; Wat. Ava.: Ensure the Sustainable Availability of Water Resources; Wat. Qual.: Maintain River Water Quality; Pro. Tour.: Protect Tourist Activities; Com. Pro.:

Promote Local Community Prosperity; Pro. Fin.: Ongoing Project Financing; Soc. App.: Encourage Social Approval 